\title{
Non-Sustained Ventricular Tachycardia in A Child After Lightning Strike
}

\section{Yıldırım Çarpmasından Sonra Bir Çocukta "Nonsustained" Ventriküler Taşikardi}

\author{
Haşim Olgun, Naci Ceviz \\ Atatürk University Faculty of Medicine, Department of Pediatric Cardiology, Erzurum, Turkey
}

\section{Keywords}

Children, electrocardiogram monitoring,

lightning strike, ventricular tachycardia

\section{Anahtar kelimeler}

Çocuk, elektrokardiyografi izlemi, yıldırım çarpması, ventriküler taşikardi

Received/Geliş Tarihi : 26.11.2013

Accepted/Kabul Tarihi : 13.02.2014

\section{DOI:10.4274/jcp.96636}

Address for Correspondence/Yazışma Adresi: Haşim Olgun MD, Atatürk University Faculty of Medicine, Department of Pediatric Cardiology, Erzurum, Turkey

Phone: +90 44223612 12-1209

E-mail: drholgun@hotmail.com

(C) The Journal of Current Pediatrics, published by Galenos Publishing. (c) Güncel Pediatri Dergisi, Galenos Yayınevi tarafından basılmıştır.

\begin{abstract}
Lightning strike is a rare natural phenomenon with a high risk of fatality. The most dramatic complications of lightning injury are those associated with the cardiovascular system, and cardiac arrest is the primary cause of death. Rhythm problems often lead to death in the acute phase of lightning strike, but recording rhythm problems in the acute phase is very difficult. We described a child who suffered a lightning strike and developed cardiac arrest shortly after admission to the emergency department. He had transient ischemic electrocardiogram (ECG) changes and non-sustained ventricular tachycardia (VT) on Holter monitoring and was treated with lidocaine.
\end{abstract}

Öz

Yıldırım çarpması yüksek ölüm riski taşıyan nadir bir doğa olayıdır. Yıldırım çarpmasının en dramatik komplikasyonu kardiyovasküler sistem ile ilişkili olanlardır ve kardiyak arrest başlıca ölüm nedenidir. Yıldırım çarpmasının akut döneminde ölüme genellikle ritim problemleri yol açar ancak akut dönemde ritim problemlerini kayıt altına almak çok zordur. Biz yıldırım çarpmasına maruz kalan ve acil servise getirilmesinden kısa süre sonra kardiyak arrest gelişen bir çocuk olguyu tanımlıyoruz. Olgunun elektrokardiyografisinde (EKG) geçici iskemik değişiklikler ve Holter kaydında ventriküler taşikardi (VT) vardı ve lidokain ile tedavi edildi.

\section{Introduction}

Lightning strike is a rare natural phenomenon that carries a risk of dramatic medical complications to multiple organ systems and a high risk of fatality. The known cardiac complications include: myocardial infarction, arrhythmia (rhythm disorders caused by a lightning strike can be recorded rarely), and cardiac contusion (1-6). The primary cause of death in victims of lightning strike or other electrical trauma is cardiac or respiratory arrest. In this report, we describe a child who developed transient ischemic electrocardiogram (ECG) changes and non-sustained ventricular tachycardia (VT) after lightning strike.

\section{Case Report}

An 11-year-old boy was brought to the emergency room due to lightning strike. The strike occurred when the child was in the 
countryside. Extensive burns covered his body. The exact entrance and exit wounds of the strike were not known, but erythematous ferning marks on the soles of his feet, singed hair and erythema on the right parietal area were noted. The patient was comatose, and was intubated and supported with positive pressure ventilation. Cardiac arrest developed shortly after admission to the emergency department. Cardiopulmonary resuscitation was done, and cardiac rhythm normalized.

The initial laboratory investigation revealed creatine phosphokinase of 4139 (55-197) U/L, creatine kinase MB fraction (CK-MB) 876, blood urea nitrogen (BUN): 54.67, creatinine 1.3, potassium (K) 5.7 (3.5$5.2) \mathrm{mmol} / \mathrm{L}$ and troponin $\mathrm{I}>25(0.000-0.060) \mathrm{mcg} / \mathrm{L}$ consistent with a diagnosis of rhabdomyolysis.

A 12-lead ECG (Figure 1) showed sinus rhythm with a heart rate of $115 \mathrm{bpm}, \mathrm{ST}$ elevation in D3, aVF, and V3, late transition shift, and $\mathrm{rS}$ pattern in leads I and aVL, and QTc was measured as $420 \mathrm{~ms}$.

Transthoracic echocardiogram revealed paradoxical septal movements and mild left ventricular systolic dysfunction (left ventricular ejection fraction $=55 \%$ ) with minimal pericardial effusion. Chest radiography demonstrated vascular cephalization with pulmonary edema. The patient was extubated the next day.

Wide QRS tachycardia and cardiac arrest developed 22 hours after hospitalization. The patient responded to the cardiopulmonary resuscitation once again, and lidocaine infusion was started. Non-sustained VT episodes were recorded in 24-hour Holter monitoring (Figure 2). After the 48-hour lidocaine infusion, tachycardia resolved. Lidocaine infusion was stopped and VT did not recur. Follow-up Holter monitoring was normal.

\section{Discussion}

Lightning injuries can occur from a direct strike, contact with a struck object or splash deflected off another object, as a result of ground currents or as blunt trauma from the lightning shockwave. The exact nature of the lightning strike exposure in our patient was unclear. Lightning differs from conventional electrical injuries in that it delivers a massive unidirectional impulse of current (2). Ghezzi (3) explained that many factors determine the degree of injury, such as the duration of the individual's contact with the lightning

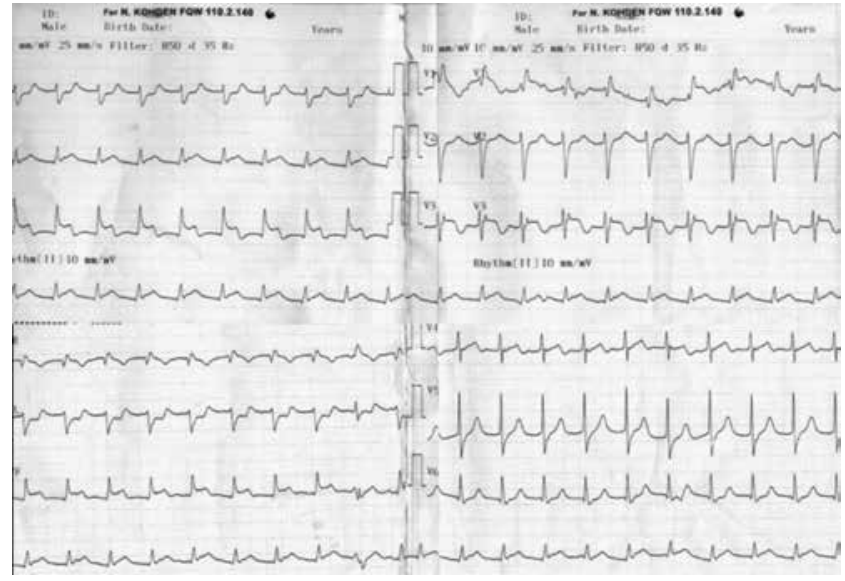

Figure 1. The patient's 12-lead electrocardiogram showed ischemic changes

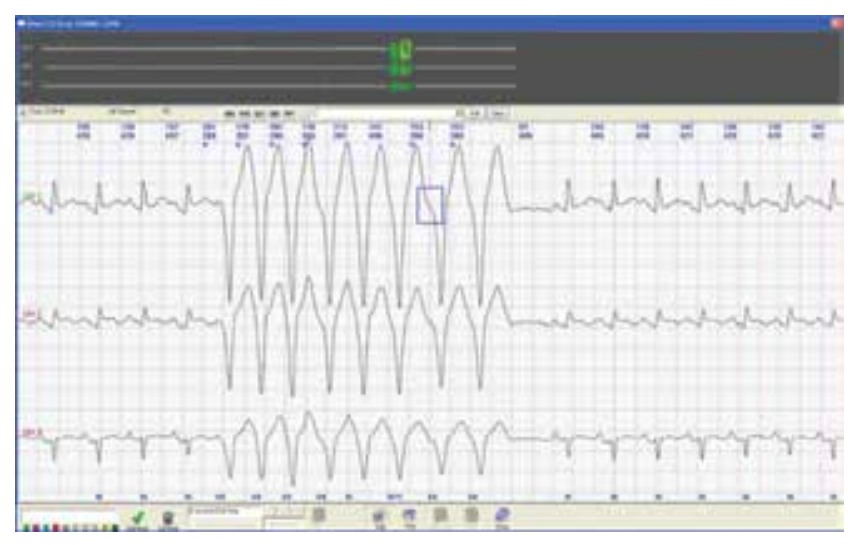

Figure 2. The patient's 24-hour Holter recording showed nonsustained ventricular tachycardia episodes

and the voltage, amperage, and resistance involved with the event. A direct strike is the most dangerous as opposed to an indirect hit off another object (side flash) or nearby ground (ground strike). Blunt injury is another mechanism by which lightning can inflict bodily damage, secondary to its explosive force as it passes through the air (4).

Lightning causes damage to humans due to its high temperature and electromechanical forces (1). Early recognition of lightning injury syndromes and anticipation of complications may help in improving outcomes for these patients. Among the most dramatic complications of lightning injury are those associated with the cardiovascular system. The cardiac complications associated with lightning injury are widespread and range in severity from benign ECG changes to death (5). Lightning strike results in a high 
incidence of cardiac injury that can be manifested early as life-threatening arrhythmias (LTA) and cardiac dysfunction. Myocardial injury may develop early in the lightning-injured individual, and later-onset arrhythmias are possible. Ventricular dysfunction is reversible even when severe (6). Our patient had only nonspecific ST-T wave changes on ECG and minimal echocardiographic abnormalities when he admitted to the pediatric emergency department.

Abnormalities on ECG also vary with the type of strike and current of injury. ST elevation and QTc interval prolongation were reported in victims of a direct hit. ECG changes after splash and ground strikes were limited to nonspecific ST-T wave changes. Marked T-wave inversion with ST depression can be seen without associated central nervous system or coronary abnormalities and appears secondary to the lightning strike. Late sequelae were limited to a single case of recurrent pericarditis. Pericarditis did not occur in our patient as a late sequela.

Cardiac dysfunction including severe biventricular failure is reversible within two weeks (6). Our patient developed paradoxical septal movements as demonstrated by echocardiography. He developed ST changes, T-wave inversion, and a rise in biochemical markers of myocardial injury after lightning strike, and pulmonary edema. In this setting, the myocardial injury could result from direct tissue damage from the lightning strike (contusion) or from lightning-induced vasospasm.

Supraventricular tachycardia, pulseless, transient asystole, atrial fibrillation, and ventricular fibrillation are the most frequently reported lightning-related arrhythmias (6-8). In our patient, cardiac arrest developed shortly after admission to the emergency department, and wide QRS tachycardia and cardiac arrest recurred 22 hours after hospitalization. Non- sustained VT episodes were recorded in 24-hour Holter monitoring. Tachycardia was controlled with lidocaine treatment. This case highlights the importance of ECG monitoring in the seemingly stable lightning-injured patient. Because of the high incidence of cardiac involvement, it is recommended that all lightning strike patients be continuously and closely monitored for the early development of potentially LTA or cardiac dysfunction. As was observed in our patient, a number of patients have been shown to develop rhythm disturbances after lightning strike. Typically, these patients recover spontaneously after treatment with supportive measures, as did our patient.

In conclusion, lightning strikes can have serious adverse effects on the heart. Patients who are struck by lightning should be monitored for myocardial ischemia, left ventricular systolic dysfunction and malignant arrhythmias.

\section{References}

1. Browne BJ, Gaasch WR. Electrical injuries and lightning. Emerg Med Clin North Am 1992;10:211-29.

2. Gatewood MO, Zane RD. Lightning injuries. Emerg Med Clin N Am 2004;22:369-403.

3. Ghezzi KT. Lightning injuries. A unique treatment challenge. Postgrad Med 1989;85:197-208.

4. Cooper MA. Electrical and lightning injuries. Emerg Med Clin North Am 1984;2:489-501.

5. Hayashi M, Yamada H, Agatsuma T, Nomura H, Kitahara O. A case of takotsubo-shaped hypokinesis of the left ventricle caused by a lightning strike. Int Heart J 2005;46:933-8.

6. Lichtenberg R, Dries D, Ward K, Marshall W, Scanlon P. Cardiovascular effects of lightning strikes. J Am Coll Cardiol 1993;21:531-6.

7. Whitcomb D, Martinez JA, Daberkow D. Lightning injuries. South Med J 2002;95:1331-4.

8. Fish RM. Electric injury, part III: cardiac monitoring indications, the pregnant patient, and lightning. J Emerg Med 2000;18:181-7. 